\title{
The potency of Chloropyrifos and Camphor extract on Spodoptera littoralis (BOISD.)
}

Hanan H. Osman, Badr El-Sabah A.Fetoh andAbeer M. Mohammad Plant protection research institute, A.R.C., Dokki-Giza, Egypt

\section{ABSTRACT}

The biological and biochemical effects chloropyrifos, camphor extract and their combination were studied against the $4^{\text {th }}$ instars of Spodoptera littoralis under semi-field conditions. The results indicated that the $\mathrm{LC}_{50}$ for chloropyrifos was 0.08 ppm and $13.3 \times 10^{3} \mathrm{ppm}$ for the camphor extract. The estimated Co-toxicity factor was 13.2 So, there is an additive effect between camphor oil and chloropyrifos against S. littoralis.

Oil extract of camphor prolonged larval and pupal duration also the same effect happened when using mixture of camphor extract and chloropyrifos. This prolongation was accompanied with a reduction in pupal weight of the treated larvae. While when using chloropyrifos only the larval and pupal duration were shortened Also $\%$ of pupation and $\%$ of adult emergence were more decrease in plant extract and insecticide mixture than each compound alone.

Biochemical studies showed that, total protein content of larval instars decreased by 31,26 and $13.5 \%$ for camphor extract, chloropyrifos and its combination, respectively. Also, the activity of acid phosphatase, $\alpha$-esterase was significantly decreased. Where the alkaline phosphatase, activity increased When compared with control.

Key Words: Spodoptera littoralis, chloropyrifos, camphor extract, Biochemical and biological effects.

\section{INTRODUCTION}

The Egyptian cotton leaf worm, Spodoptera littoralis (Boisd.), is a major polyphagous pest in Egypt and is considered one of the most dangerous pest attack cotton plants. This pest has at least 7-9 generations during the cotton season as well as infesting more than 29 other crops and vegetables of economic importance (Magd Eldin \& El-gengaihi, 2000). The increasing number of studies on plant/insect chemical interactions in the last few decades unveiled the potential of utilizing secondary plant metabolites as pest control agents (Howe and Jander 2008). The necessity to find environmentally safe insecticides, to combat species resistant to conventional pesticides, has spurred interest in alternative insecticides such as use of plant extracts (Schmutterer, 1985). Natural plant extracts play an increasingly prominent role as alternatives to synthetic pesticides due to the increasing concern on health hazards, environmental pollution and negative effects on non target organisms (Sharma et al., 2006). There are more than 2400 plant species belonging to 189 plant families which are rich sources of bioactive organic compounds (Rao et al., 2005). Species from over 60 plant families have been identified as possessing insecticidal (Prakesh \& Rao, 1997).

Camphor oil extract is a natural compound derived from the camphor tree, Eucalyptus comaldulensis was commonly used as a moth repellent (Budavari 1996). It is a feeding deterrent for the tobacco budworm (Heliothis virescens) (Lepidoptera) 
and the boll weevil (Anthonomus grandis) (Miles et al., 1985), and a repellent to four species of stored-products beetles (Sitophilus granarius, S. zeamais, Trilobium castaneum, Prostephanus truncatus) (Obeng et al.,1998). Mazyad and Soliman (2001) studied the effect of E. globulus leaves oil or camphor against the maturation of Oestrus ovis larvae. Camphor at concentrations 1 and 1.1 showed $100 \%$ mortality rate. On the other hand $27.5 \%$ of the developed pupae emerged to adults but only $36.8 \%$ of them were fertile. Camphor is safely used in Medicine. So, it is recommended in controlling the zoonotic myiasis producer and O. ovis.

The present work was aimed to evaluate the biological and biochemical aspects of chloropyrifos, camphor oil extract and their mixture on $4^{\text {th }}$ larvae of cotton leafworm Spodoptera littoralis, (Lepidoptera: Noctuidae).

\section{MATERIALS AND METHODS}

\section{Maintenance of insect culture:}

A colony of cotton leafworm, Spodoptera littoralis, obtained from Plant Protection Research Institute, was maintained in the laboratory for many generations at $27 \pm 2{ }^{\circ} \mathrm{C}$.

\section{Camphor (Eucalyptus comaldulensis) extract:}

The fresh crude extract which used in this study was supplied from Kab farm company preparation of camphor oil as emulsifiable concentrate. It was prepared as emulsifiable concentrate $90 \%(\mathrm{v} / \mathrm{v})$ by mixing $10 \mathrm{ml}$ of polyethelyne glycol 600 diolate dissolved in xylene with $90 \mathrm{ml}$ camphor base oil (Kazem, 2004). Stock solution was stored under refrigeration until needed. Four concentrations of camphor extract were prepared in water as required for the bioassay tests against the ${ }^{\text {th }}$ instars of Spodoptera littoralis (Hafez et al., 2003).

\section{Insecticide:}

Chlorpyrifos $480 \mathrm{~g} / \mathrm{L}$ EC, is a crystalline organophosphate insecticide (Dow Company, King Lynn, England) and is known by many trade names including Dursban. It acts on the nerve system of insects by inhibiting many enzymes.

Formula; o,o-diethyl $0-3,5,6$ - trichloropyridin -2 - yl phosphorothioate<smiles>CCO[PH](=S)Oc1nc(Cl)c(Cl)cc1Cl</smiles>

\section{Toxicity test:}

Seedlings of cotton plant (Gossypium barbodense L.), aged from 21-33 days were exposed to 5 different concentrations from tested compounds for 1 hour then, collected from pots, air dried and then were fed to $4^{\text {th }}$ instar larvae of Spodoptera littoralis. Five replicates were used for each concentration. For control larvae fed on untreated cotton plant leaves. For each replicate ten larvae were put in glass jar, they fed on treated cotton leaves, and then the jars were placed at room condition held at $27^{\circ} \mathrm{C} \pm 2^{\circ} \mathrm{C}$ for 2 days. Numbers of living and dead insect larvae were counted in control and treatments. Then mortality percentage was estimated and corrected according to the Abbott's formula, 1925. $\mathrm{LC}_{50}$ values were determined using probit analysis statistical method of finney, 1971. 


\section{Biological experiments:}

The effect of median lethal concentrations $\left(\mathrm{LC}_{50}\right)$ on some biological aspects of the treated instar and its subsequent developmental stages were determined as follows: fifty newly moulted $4^{\text {th }}$ instar larvae of S. littorsalis were used for each compound. Five replicates were used for each compound, ten larvae in each replicate, they fed on cotton leaves treated with median lethal concentration of camphor, chloropyrifos and their combination. In control test, leaves were treated with distilled water only. Larval and pupal duration, pupal weight $\%$ of pupation and $\%$ of adult emergence were recorded (Marie et al., 2009).

\section{Biochemical studies:}

Tissue preparation:Total body tissue samples were collected from late $6^{\text {th }}$ larval instars treated as $4^{\text {th }}$ instars fed on sprayed cotton leaves with $\mathrm{LC}_{50}$ values of two compounds and their mixture. Insect bodies were homogenized in distilled water (one gm. insect bodies $/ 5 \mathrm{ml}$ ) using a chilled glass teflon tissue grinder for $3 \mathrm{~min}$. Homogenates were centrifuged at 8000 r.p.m for $15 \mathrm{~min}$ at $-2^{\circ} \mathrm{C}$ in a refrigerated centrifuge. The supernatant can be used directly or stored at $-5^{\circ} \mathrm{C}$ until use for biochemical determination (Max-2 week). Samples of non-treated also were prepared in the same manner.

Total protein: Total proteins were determined by the method of Bradford (I976).

Phosphatase: Acid and alkaline phosphatases were determined according to the method described by Laufer and Schin (1971).

Non specific estrases: Alpha esterases ( $\alpha$-esterases) and beta esterases ( $\beta$-esterases) were determined according to Van Asperen(I962).

\section{Statistical analysis:}

All experimental data were statistically analyzed using analysis of variance and F-test (ANOVA) using software computer program.

\section{Joint action studies:}

Binary mixtures of the Camphor oil and chloropyrifos were prepared according to their toxicity equivalent $\mathrm{LC}_{25}$ values. The combined action of the mixture was expressed in as the "co-toxicity factor" according to Mansour et al. (1966), and subsequently the type of interaction (joint action) was estimated.

\section{RESULTS AND DISCUSSION}

\section{Toxicity tests and $\mathrm{LC}_{50}$ determination.}

Data presented in Table (1) and illustrated by Figs (1\& 2), showed the efficiency of chloropyrifos and Camphor extract against the $4^{\text {th }}$ instars of $S$. littoralis under semifield conditions. In general, data revealed that, chloropyrifos higher active against the larvae, with $\mathrm{LC}_{50}=0.0848 \mathrm{ppm}$ than Camphor extract $\mathrm{LC}_{50}=13.3 \times 10^{3} \mathrm{ppm}$, in comparison with control treatment.

Table (1): Efficacy of Camphor extract and Chloropyrifos against S. littoralis.

\begin{tabular}{|c|l|l|l|l|l|l|l|}
\hline & $\begin{array}{c}\mathrm{LC}_{25} \\
\mathrm{ppm}\end{array}$ & $\begin{array}{c}\text { Lower } \\
\mathrm{ppm}\end{array}$ & $\begin{array}{c}\text { Upper } \\
\mathrm{ppm}\end{array}$ & $\begin{array}{c}\mathrm{LC}_{50} \\
\mathrm{ppm}\end{array}$ & $\begin{array}{c}\text { Lower } \\
\mathrm{ppm}\end{array}$ & $\begin{array}{c}\text { Upper } \\
\mathrm{ppm}\end{array}$ & $\begin{array}{c}\text { Slope } \\
(b)\end{array}$ \\
\hline $\begin{array}{c}\text { Camphor } \\
\text { extract }\end{array}$ & 0.64 & $\begin{array}{l}0.095 \\
\mathrm{x} 10^{3}\end{array}$ & $\begin{array}{l}1.07 \\
\mathrm{x} 10^{3}\end{array}$ & $13.3 \times 10^{3}$ & $7.8 \times 10^{3}$ & $19.1 \times 10$ & 0.9431 \\
\hline Chloropyrifos & 0.0379 & 0.0217 & $\begin{array}{l}0.053 \\
5\end{array}$ & 0.0848 & 0.0616 & 0.1113 & 1.9298 \\
\hline
\end{tabular}




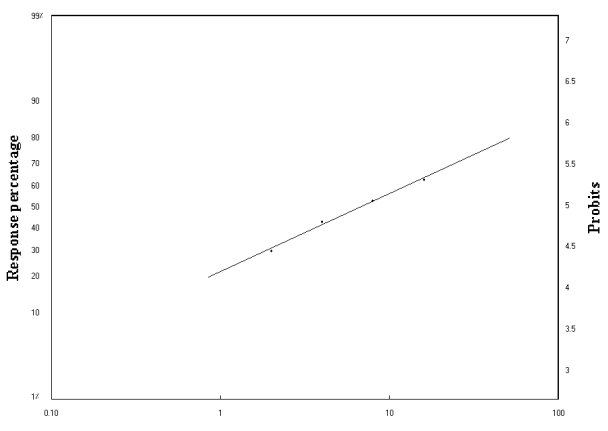

Fig.( 1 ): Efficacy of camphor extract against the $4^{\text {th }}$ larval instar of S. littoralis.

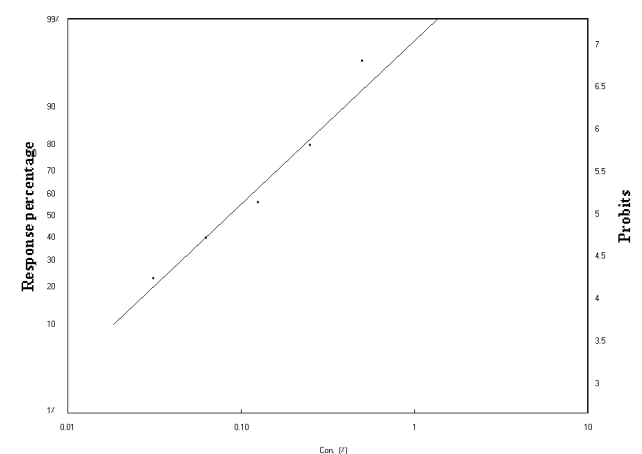

Fig.( 2 ): Efficacy of chloropyrifos against the $4^{\text {th }}$ larval instar of $S$. littoralis.

\section{Joint action analysis:}

Camphor oil mixed with chloropyrifos insecticide at $\mathrm{LC}_{25}$ level of each as tested against $4^{\text {th }}$ larval instars of $S$. littoralis.

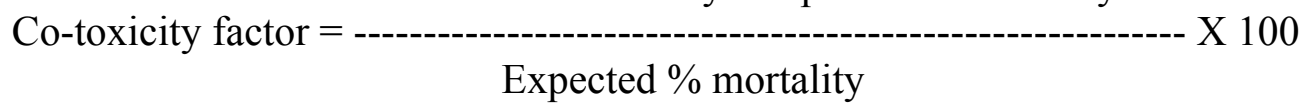

Observed \% mortality $=56.6$

Expected $\%$ mortality $=50$

Calculated Co-toxicity factor $=13.2$

So, there is additive effect between camphor oil mixed with chloropyrifos against $4^{\text {th }}$ instar S. littoralis larvae. (Co-toxicity factor $=$ less 20).

\section{Effect of tested compounds on the developmental stages of $S$. littoralis:}

The $4^{\text {th }}$ instars of $S$. littoralis were treated with a concentration of $\mathrm{LC}_{50}$ of chloropyrifos, camphor extract and combination, then let for reaching the adult. Larval duration, pupal duration and pupal weight were observed daily; also \% pupation and \% adult emergence were recorded. Data presented in Table (2), presented that there is no remarkable effect on development of larvae with chloropyrifos, camphor extract, while there is a slight increase in larval duration when mixture was used, compared with control larvae. Pupal duration was not affected with regard to control ones except for larvae fed on cotton leaves treated with chloropyrifos as it lasted only 9 days while that of control lasted 15 days. There was a remarkable decrease in pupal weight as it was $0.232,0.274$ and $0.203 \mathrm{~g}$ when using chloropyrifos, camphor extract and mixture, respectively comparing to 0.313 of control larvae. The percentage of both pupation and adult emergence were presented in Table (3). The \% of pupation was highly reduced from 97 (control) to $31.3 \%$ after 
larval feeding with mixture of camphor extract and chloropyrifos, while it was $33 \%$ when using camphor extract only and it was $37 \%$ with chloropyrifos treatment.

Percentage of adult emergence also decreased from $94.2 \%$ for control treatment to $77 \%$ when mixture of chloropyrifos and camphor extract was used. The decrease reached $81 \%$ with using camphor extract only, and it was $85.3 \%$ when using chloropyrifos. Insecticidal effect of Sorghum extract on the cotton leaf worm Spodoptera littoralis, were recorded by Hafez et al., 2003. It was markedly affected the viability of eggs, shortening of adult longevity and reducing egg production. Also, Jojoba and Sesame oil were used by Marie et al., 2009 to evaluate their effects on the cotton leaf worm Spodoptera littoralis. They found that, there was a significant reduction in the efficiency of larvae to convert digested and ingested food into body tissue.

Table (2): Effect of camphor extract, Chloropyrifos and their mixture on some biological aspects of Spodoptera littoralis.

\begin{tabular}{|c|c|c|c|}
\hline Treatment & $\begin{array}{c}\text { Mean larval duration } \\
(\text { days })\end{array}$ & $\begin{array}{c}\text { Mean pupal duration } \\
(\text { days })\end{array}$ & Mean pupal weight (g) \\
\hline Camphor extract & $12.00^{\mathrm{a}} \pm 0.913$ & $14.50^{\mathrm{a}} \pm 0.644$ & $\mathbf{0 . 2 3 2}^{\mathbf{b c}} \pm \mathbf{0 . 1 8 5}$ \\
\hline Chloropyrifos & $10.50^{\mathrm{c}} \pm 0.646$ & $9.50^{\mathrm{b}} \pm 0.645$ & $\mathbf{0 . 2 7 4}^{\mathbf{a b}} \pm \mathbf{0 . 0 2 4}$ \\
\hline Mixture & $13.00^{\mathrm{a}} \pm 0.913$ & $15.5^{\mathrm{a}} \pm 0.646$ & $\mathbf{0 . 2 0 3}^{\mathbf{c}} \pm \mathbf{0 . 0 0 1 7}$ \\
\hline Control & $11.75^{\mathrm{b}} \pm 0.854$ & $13.75^{\mathrm{a}} \pm 0.854$ & $\mathbf{0 . 3 1 3}^{\mathbf{a}} \pm \mathbf{0 . 0 0 8}$ \\
\hline F- value & $1.5037^{\mathrm{ns}}$ & $14.0947^{* * *}$ & $\mathbf{9 . 3 8 3 3}^{* *}$ \\
\hline LSD (5 \%) & 2.584 & 2.1674 & $\mathbf{0 . 0 5 1 2 7}$ \\
\hline
\end{tabular}

Means with the same letter are not significantly different $(\mathrm{p}<0.05)$. ns: not significant

${ }^{* *}:$ moderately significant $(\mathrm{p}<0.01) \quad{ }^{* * *}$ : highly significant $(\mathrm{p}<0.001)$.

Table (3): Effect of camphor extract, Chloropyrifos and their mixture on Pupation \% and Adult emergence $\%$ of Spodoptera littoralis

\begin{tabular}{|c|c|c|}
\hline Treatment & \% of pupation & \% of adult emergence \\
\hline Camphor extract & 33 & 81 \\
\hline Chloropyrifos & 37 & 85.3 \\
\hline Mixture & 31.3 & 77 \\
\hline Control & 97 & 94.2 \\
\hline
\end{tabular}

\section{Biochemical aspects:}

Proteins are major biochemical components necessary for an organism to develop, grow and perform its vital activities (Elbarky et al., 2008). Mean values of protein content were determined in the $6^{\text {th }}$ instars treated with $\mathrm{LC}_{50}$ of chloropyrifos, camphor extract and combination. From the data recorded in Table (4) it was showed that, total protein was significantly decrease by $31 \%$ with camphor extract and by 26 $\%$ with chloropyrifos compared to $13.5 \%$ when combination of them was used. Elbarky et al., 2008 suggested that, the reduction of protein content may be due to inhibition of DNA and RNA synthesis.

Table (4): Total protein content of $6^{\text {th }}$ instars of Spodoptera littoralis treated with $\mathrm{LC}_{50}$ of chloropyrifos, camphor extract and their combination.

\begin{tabular}{|c|c|c|}
\hline $\begin{array}{c}\text { Tratment } \\
(\mathrm{ppm})\end{array}$ & $\begin{array}{c}\text { Total protein content } \\
\text { (mg/g.b.wt.) } \\
\text { Mean } \pm \mathrm{SE}\end{array}$ & decrease \% \\
\hline Camphor extract & $9.21 \pm 0.11$ & 31 \\
\hline Chloropyrifos & $9.89 \pm 0.26$ & 26 \\
\hline Mixture & $11.57 \pm 0.12$ & 13.5 \\
\hline Control & $13.37 \pm 0.32$ & -- \\
\hline
\end{tabular}


Results indicated in Table (5) showed that the activity of acid phosphatase slightly decreased by $-0.01 \%,-0.08 \%$ and $-0.16 \%$ when using camphor extract, chloropyrifos and combination of them, respectively compared with control treatment. While alkaline phosphatase activity was increased significantly by $1.77,0.50$ and 0.75 with camphor extract, chloropyrifos and combination, respectively, Table (6).

Table (5): Acld phosphatase activity of $6^{\text {th }}$ instars of Spodoptera littoralis treated with $\mathrm{LC}_{50}$ of chloropyrifos, camphor extract and their combination.

\begin{tabular}{|c|c|c|}
\hline Treatments & $\begin{array}{c}\mathrm{UX} 10^{3} / \text { g.b.wt. } \\
\pm \mathrm{SE}\end{array}$ & $\%$ activity \\
\hline Camphor extract & $92.66 \pm 1.201$ & -0.01 \\
\hline Chloropyrifos & $84.66 \pm 2.905$ & -0.08 \\
\hline Mixture & $77.00 \pm 2.516$ & -0.16 \\
\hline Control & $91.66 \pm 0.881$ & -- \\
\hline
\end{tabular}

Table (6): Alkaline phosphatase activity of $6^{\text {th }}$ instars of Spodoptera littoralis treated with $\mathrm{LC}_{50}$ of chloropyrifos, camphor extract and their combination.

\begin{tabular}{|c|c|c|}
\hline Treatments & $\begin{array}{c}\text { UX10 } / \text { g.b.wt. } \\
\pm \mathrm{SD}\end{array}$ & \% activity \\
\hline Camphor extract & $103.66 \pm 1.855$ & 1.27 \\
\hline Chloropyrifos & $54.33 \pm 1.201$ & 0.50 \\
\hline Mixture & $63.66 \pm 0.6667$ & 0.75 \\
\hline Control & $39.66 \pm 2.666$ & -- \\
\hline
\end{tabular}

In respect to $\alpha$ and $\beta$ esterase, results showed variable values with the two studied compounds or with their mixture. $\alpha$ - esterase decreased by $-0.14,-0.185$ and $0.024 \%$ relative to control treatment. While, on opposite trend was found in $\beta$ esterase activity which increased with chloropyrifos and the combination by 0.49 and $0.039 \%$, but, when using camphor extract the activity decreased by $-0.421 \%$ as shown in Tables (7\&8).

Table (7): $\alpha$-esterase avtivity of $6^{\text {th }}$ instars of Spodoptera littoralis treated with $\mathrm{LC}_{50}$ of chloropyrifos, camphor extract and their combination.

\begin{tabular}{|c|c|c|}
\hline Treatments & $\begin{array}{c}\text { Ug alpha naphthol / min/g.b.wt. } \\
\pm \mathrm{SD}\end{array}$ & $\%$ activity \\
\hline Camphor extract & $71.36 \pm 2.10739$ & -0.14 \\
\hline Chloropyrifos & $67.33 \pm 1.49370$ & -0.185 \\
\hline Mixture & $83.200 \pm 2.369$ & -0.024 \\
\hline Control & $82.66 \pm 2.095$ & --- \\
\hline
\end{tabular}

Table (8): $\beta$ - esterase avtivity of $6^{\text {th }}$ instars of Spodoptera littoralis treated with $\mathrm{LC}_{50}$ Of chloropyrifos, camphor extract and their combination.

\begin{tabular}{|c|c|c|}
\hline Treatments & $\begin{array}{c}\text { Ug beta naphthol / min/g.b.wt. } \\
\pm \mathrm{SD}\end{array}$ & $\%$ activity \\
\hline Camphor extract & $51.74 \pm 3.920$ & -0.421 \\
\hline Chloropyrifos & $133.43 \pm 4.45$ & 0.049 \\
\hline Mixture & $92.87 \pm 1.510$ & 0.039 \\
\hline Control & $89.39 \pm 2.618$ & -- \\
\hline
\end{tabular}

Many trials for using several plant extracts against larvae of Spodoptera littoralis were mentioned by many authors. In general, all these trials recorded inhibitory effects against the larvae. Hafez et al., 2003 stated that, sorghum seedlings extract reducing of consumed food amount. Decreasing in larval growth by extract of 
Reynoutria sp. ( Pavela et al.,2008). Prolongation in larval and pupal duration (Marei et al.,2009) and increasing or decreasing in enzyme activity (Hafez et al.,2003 \& Marei et al.,2009). Decreasing in total lipids, total proteins and glucose content (Rawi et al., 2011). In similar studies to ours, Shonoda et al., 2012, tested the efficacy of the botanical extract (myrrh), chemical insecticide and their combination on the cotton leafworm Spodoptera littoralis, results showed the strong efficacy of the botanical extract which could be used alone or in combination with $\mathrm{LC}_{50}$ of the insecticide. Also, Hazaa, 2005 studied the effect of $\lambda$-radiation and leaf extract of camphor against $4^{\text {th }}$ instars of Spodoptera littoralis on food consumptions aspects, which found to be reduced significantly.

\section{REFERENCES}

Abbott, M. S. (1925). A method of computing the effectiveness of an insecticide. J. Econ. Entomol. 18: 265-267.

Bradford, M. M. (1976). A rapid and sensitive method for the quantitation of microgram quantities of proteins utilizing the principles of protein-dye binding. Anal. Biochem.72: 248-254.

Budavari, S. (1996). The Merck Index: an encyclopedia of chemicals, drugs, and biologicals. $12^{\text {th }}$ edition. Merck, Whitehouse Station, NJ, USA. $1741 \mathrm{p}+$ app.

Elbarky, Nehad, M.; Dahi, H. F. and El-Sayed, Y. A. (2008). Toxicological evaluation and biochemical impacts for radient as a new generation of spinisyn on Spodoptera littoralis larvae. Egypt Acad. J. Biolg. Sci., 1(2): 8597.

Hafez, M.; Matter, M.M. and Younes, A.A. (2003). Entomological effects of Sorghum seedlings extract on the cotton leafworm and its parasitoid, Microplitis rufiventris.Pakistan Journal of Biological Sciences , 6(19), 16491654.

Hazaa, M. A. (2005). Influence of red gum plant extract and gamma radiation on the nutrition of the cotton leafworm Spodoptera littoralis. Isotop.\& Rad. Res., 37 (6): 1547-1561.

Howe, G.A. and Jander, G. (2008). Plant Immunity to Insect Herbivores Annual Review of Plant Biology, 59: 41-66.

Kazem,M.G.(2004). Formulation and evaluation of some local natural products against some pests, Ph.D. thesis, Agric. Fac.,Cairo University

Litchfield, J. T. and Willcoxon, F. (1949). A simplified method of evaluating dose effect experiments. J. Pharmacol. Exp. Therap. 96, 99 - 133.

Laufer, I. I. and Schin, K. S. (1971). Quantitative studies of hydrolic enzymes activity in the salivary gland of Chironomous tentans (Diptra) during metamorphosis. Can. Entomol. 103:454-457.

Magd El-Din and El-Gengaihi, S. E. (2000). Joint action of some botanical extracts against the Egyptian cotton leafworm Spodoptera littoralis Bosid (Lepidoptera: Noctuidae). Egypt. J. Biol. P. Cont. 10 (1): 51-56.

Makkar, A. W. and ElMandarawy Monna, B. R. (1996). Laboratory studies for increasing the efficacy of a bioinsecticide against Spodoptera littoralis larvae. Annals of Agric. Sci., Moshtohor, 34 (4): 1925 - 1934.

Marie, S.S; Amr, E.M. and Salem, N.Y. (2009). Effect of some plant oil on biological, physiological and biochemical aspects of Spodoptera littoralis. Res. J. Agric. And Biochem. Scie., 2(1): 103-107. 
Mansour, N.A.; El-Defrawi, M.E.; Toppozada, A. and Zeid, M. (1966). Toxicological studies on the Egyptian cotton leaf-worm, Prodenia litura. VI. Potentiation and antagonism of organophosphorus and carbamate insecticides. J. Econ. Entomol., 59(2): 307-311.

Mazyad, S. A. and Soliman, M. (2001). Laboratory evaluation of the insecticidal activity of camphor on the development of Oestrus ovis larvae. J Egypt Soc Parasitol. Dec;31(3):887-92

Miles, D. H.; Hankinson, B. L.and Randle, S. A. (1985). Insect antifeedants from the Peruvian plant Alchornea triplinervia. pp. 469 ñ476 in Hedin, P.A. (Ed.): Bioregulators for pest control.American Chemical Society, Washington, DC, USA. ACS Symposium Series 276 (abstract only seen).

Obeng, O.D.; Reichmuth, C.H.; Bekele, A.J.and Hassanali, A. (1998) Toxicity and protectant potential of camphor, a major component of essential oil of Ocimum kilimandscharicum, against four stored product beetles. International Journal of Pest Management 44: 203-209.

Pavela, R.; Vrchotova, N. and Sera, B. (2008). Growth inhibitory effect of extracts from Reynoutria sp. Plants against Spodoptera littoralis. Agrociencia 42(5):1405-1413.

Prakesh, A. and Rao, J. (1997). Botanical Pesticides in Agriculture. Boca Raton, USA: CRC Press.

Rao, N.V.; Maheswari, T.U. and Manjula. K. (2005). Review on Botanical Pesticides as Tools of Pest Management, pp: 1-16. Narosa Publishing House Pvt., Ltd

Rawi, S.M.; Bakry, F.A. and Al-Hazm, M.A. (2011). Biochemical and histopathological effect of formulated and non formulated plant extract on Spodoptera littoralis. International Research J. Plant Scie. 2(4): 107-118.

Sharma, A.; Kaushal, P.; Sharma, K.C. and Kumar, R. (2006). Bioefficacy of some plant products against Diamondback moth Plutella xylostella L. (Lepidoptera: Yponomeutidae). J. Entomo. Res. Soc., 30: 213-217.

Schmutterer, H. (1985): Which insect bests can be controlled by application of neem seed kernel extracts under field conditions. Z.ang. Ent., 100: 458-475.

Shonoda, M.L.;.Farrag, R.M and Salama, O.M. (2012). Efficacy of the botanical extract (myrrh), chemical insecticides and their combination on the cotton leaf worm Spodoptera littoralis. Puplished on Alexandria University (http://www.alexu.edu.eg).

Van Aspersen, K.(1962). A study of house flies esterase by means of sensitive colourimetric method. J.Insect physiol. 8:401-416. 


\section{ARABIC SUMMARY}

\section{فاعليه الكلوروبيروفوس ومستخلص الكافورعلى دوده ورق القطن

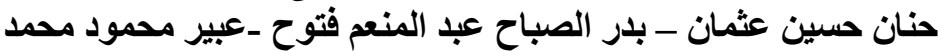

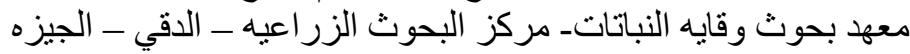

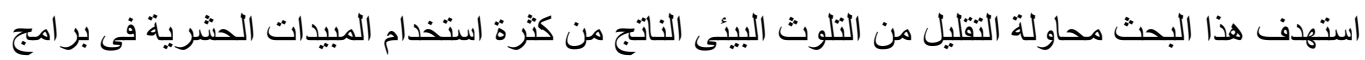

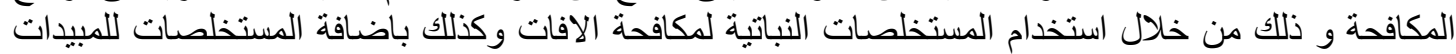

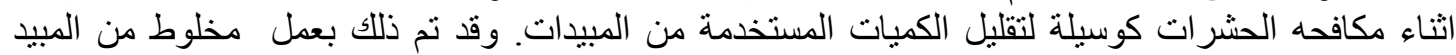

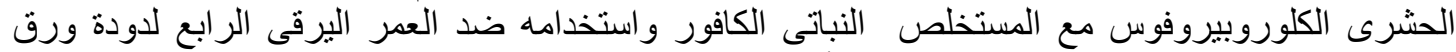

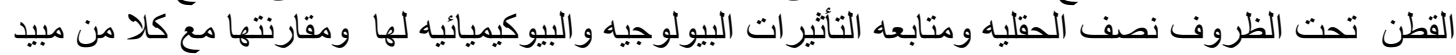

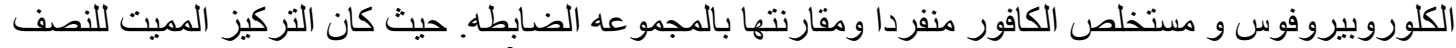

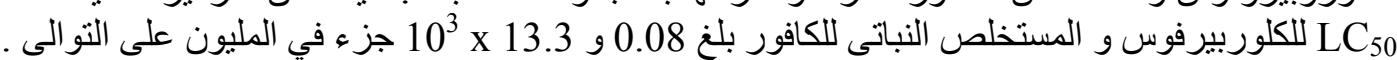

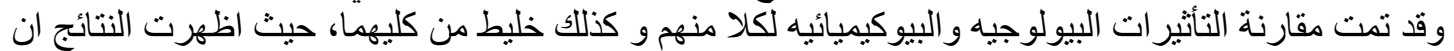

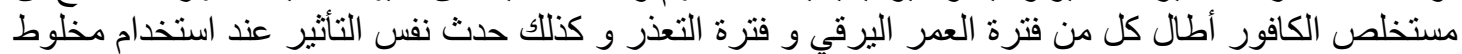

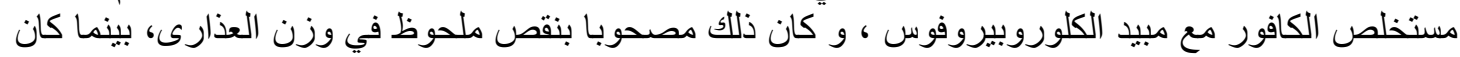

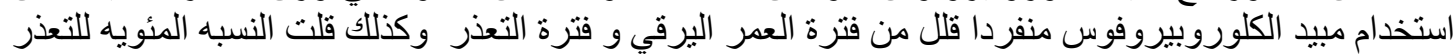

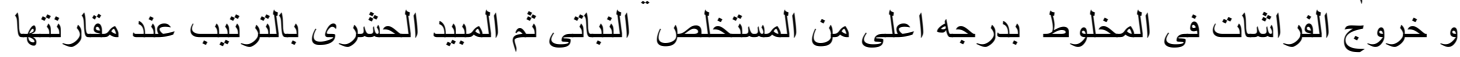
بالمجمو عهد الضابطه.

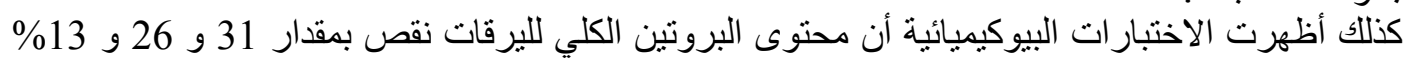

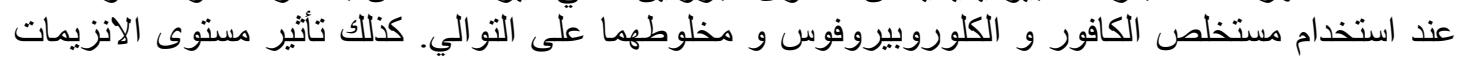

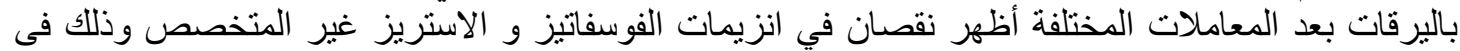
عمر ها السادس بمقارنتها بالمجمو عاده الضابطه المنان 